\title{
Relationship With Pranikah Sex Behavior In Adolescents Of High Schools In Bulukumba District
}

\author{
Fatmawati ${ }^{1}$, Irfanita Nurhidayah ${ }^{2}$, Nila Arfila ${ }^{3}$ \\ Departemen Mental Health Nursing, Stikes Panrita Husada Bulukumba ,Indonesia ${ }^{1}$ \\ Departemen Medical Surgical Nursing , Universitas Syiah Kuala, Indonesia ${ }^{2}$ \\ S1 Nursing Study Program, Stikes Panrita Husada Bulukumba, Indonesia ${ }^{3}$
}

Corresponding Autor : ․ㅡgfatma@gmail.com

\begin{abstract}
ABSTRAK
Premarital sexual behavior in adolescents has increased from year to year which has an impact on the quality of adolescents, at risk of contracting HIV / AIDS, early marriage, unwanted pregnancy, and continued abortion. Teenage knowledge about the dangers of premarital sexual behavior is very little. The family still considers taboo everything related to sex and counseling from the government or the school is still lacking. While adolescent relationships are now increasingly difficult to control. This study aims to determine the relationship of promiscuity with premarital sexual behavior in high school adolescents in 2018. The design of this study uses analytic observational research with a cross-sectional approach. The population in this study was all 118 high school students with a random sampling technique with a systematic random sampling approach to modification of simple random sampling. The number of samples in this study was 55 people. Data obtained through questionnaires made by researchers to respondents who have tested the validity. Data analysis used the Chi-square test with significance level $\alpha=0.05$. The results of the data analysis show that $p=0.00$ means that there is a relationship between promiscuity and premarital sex behavior among high school adolescents in Bulukumba in 2018. From the results of this research, suggestions that can be given to related institutions, in this case, the Health Office and high school schools can increase counseling about premarital sexual behavior in adolescents at an early stage and need to limit relationships between adolescent boys and girls.
\end{abstract}

Keywords: Intercourse, Premarital Sex Behavior

\section{INTRODUCTION}

Teenage pregnancy rates in the UK are among the highest one of them in Europe (46.6\%) of pregnancies per 1000 women aged 15-17 years (WHO 2016). While in the United States sexual relations carried out by adolescents turned out to have increased by about $1 \%$ annually. $40 \%$ of teenage girls get pregnant before completing high school, $50 \%$ of them have an abortion and the rest give birth to their baby (Soetjiningsih, 2010). Indonesian Teenage Reproductive Health Survey Report (SKRRI) where adolescent boys aged 15-24 years claimed to have had premarital sexual relations and increased by 6.4 in 2007 to $8.3 \%$ in 2012. While premarital sexual behavior in women decreased from $1.3 \%$ in 2007 to $0.9 \%$ in 2012 . In general, there were more boys who 
said they had had premarital sex compared to girls (Info Datin Center for Data and Information of the Ministry of Health Republic of Indonesia, 2014 ).

In South Sulawesi, the percentage of underage teenage marriages before the age of 15 years from 2008-2012 with an average of 3.8\% ranked fifth after West Sulawesi (5.6\%) which ranks first (Jakarta-Indonesia Central Statistics Agency, 2008 2012). While the phenomenon that occurred in Bulukumba was a sex party carried out by a group of teenagers precisely on Jl. Pisang Kelurahan Loka, Bulukumba Regency. The Civil Service Police Unit secured six teenage girls after the glue party, in addition to the teenage girls also being secured by two young men, one of whom was a homeowner who was allegedly a place to have free sex. The head of the municipal police said that if the six teenage girls were commercial sex workers (CSWs) operating through social media. Because there were several women who were repeatedly safeguarded, from the arrest of this teenager, there were dozens of used evidence of Fox glue and used condoms (Rakyatku.com, 2018).

Sexual behavior in unhealthy adolescents can reduce the quality of adolescents, at risk of contracting HIV / AIDS, early marriage, unwanted pregnancy, and continued abortion (Abdissa, Addisie, \& Seiful, 2015). Pregnancy in adolescents is at risk of premature birth, low birth weight (LBW) labor bleeding, which can increase maternal and infant mortality (Info Datin Data Center and information Ministry of Health Republic of Indonesia, 2014).

Sexual behavior in adolescents is influenced by several factors including relationships that tend to be free or deviate that cross the limits of the rules. Peers are the social environment of a teenager. Through interaction with individual friends will get acquainted and start hanging out with friends to then form groups if the behavior of the friend feels appropriate. The adolescent association can affect positive and negative behavior. The positive influence in question is when the individual with his friends carry out useful activities such as conducting study groups and adhering to the norms in society. While negative influences can be in the form of violations of social norms including premarital sexual behavior. Premarital sexual behavior is sexual behavior carried out without going through an official marriage process according to law or according to their respective religions and beliefs (Darmayanti.y, Lestari, \& Ramadani , 2011). 


\section{MATERIAL AND METHODS}

This type of research is an observational study with a cross-sectional design. This research was conducted at Muhammadiyah High School in Bulukumba, Bulukumba Regency, South Sulawesi, Indonesia. The population of this research is all students of Muhammadiyah Bulukumba High School as many as 118 in 2018. The sampling technique used was random sampling with a systematic random sampling approach with a total sample of 55 people. Data collected included sex, age, adolescent sex, premarital sexual behavior in adolescents. This study uses a research instrument in the form of a questionnaire on both variables, namely promiscuity and premarital sexual behavior. The results of the study were processed using the SPSS program. Data analysis includes univariate and bivariate analysis Univariate analysis to describe the frequency distribution of each variable. Bivariate analysis using chi-square test.

\section{RESULTS}

Table 1 Frequency distribution of respondent characteristics

\begin{tabular}{ccc}
\hline Gender & Frequency & Percentage (\%) \\
Male & 36 & 65,5 \\
Female & 19 & 34,5 \\
Age & & \\
Early teens & 0 & 0 \\
Late teens & 55 & 100 \\
\hline Amount & $\mathbf{5 5}$ & $\mathbf{1 0 0}$ \\
\hline
\end{tabular}

Based on table 1, it can be seen that the gender characteristics of the respondents indicate that more than half of the respondents were male, as many as 36 people (65.5\%) and female respondents as many as 19 people (34.5\%). Sprinkle the frequency distribution of the age of respondents is the final adolescents as many as 55 people (100.0\%).

Table 2. Relationships between Relationships with Premarital Sex Treatments in Adolescents

\begin{tabular}{|c|c|c|c|c|c|c|c|c|}
\hline & & \multicolumn{4}{|c|}{ Premarital Sex Behavior } & \multirow{2}{*}{\multicolumn{2}{|c|}{ Amount }} & \multirow{3}{*}{$\begin{array}{c}P \\
\text { Value }\end{array}$} \\
\hline & & \multicolumn{2}{|c|}{ Do not do } & \multicolumn{2}{|c|}{ To do } & & & \\
\hline & & $\mathbf{N}$ & $\%$ & $\mathbf{N}$ & $\%$ & $\mathbf{N}$ & $\%$ & \\
\hline \multirow{2}{*}{ Association } & Low Risk & 12 & 52,2 & 11 & 47,8 & 23 & $100.0 \%$ & \multirow{3}{*}{0,00} \\
\hline & High Risk & 3 & 9,4 & 29 & 90,6 & 32 & $100.0 \%$ & \\
\hline & Amount & 15 & 27,3 & 40 & 72,7 & 55 & $100.0 \%$ & \\
\hline
\end{tabular}

Based on table 2 above the differences in the percentage between promiscuity of teens who are at high risk and engaging in premarital sexual behavior are 29 respondents (90.6\%) compared to promiscuity of teens who are at low risk and engaging in premarital sex as many as 11 respondents (47.8\%). Based on the results of 
the percentage it can be concluded that there is a relationship of promiscuity with premarital sexual behavior in adolescents.

Based on the results of the percentage using the chi squer test the main test results are met and the $\mathrm{p}$ value is 0.00 less than the value of $\alpha=0.05$. Thus Ho is rejected and Ha is accepted, so it can be concluded that there are differences in the proportion between promiscuity and premarital sexual behavior among teenagers in high school in 2018.

\section{DISCUSSION}

Based on the results of research conducted by SMA in Bulukumba District, there were 55 respondents, 32 respondents (58.2\%) who had high risk associations, while 23 respondents (41.8\%) had low risk associations. Adolescent association is a peer group which is a place for socialization where the values that apply are not the values set by adults, but by their peers. If the value developed in the association is a negative value it will be dangerous for the development of adolescents. Each member can not be separated in the group and will follow the group leader starting from the attitudes, thoughts, lifestyles and behavior (Fajar, Pratami, \& Purwati, 2016).

The results of this study are supported by research (Fajar, Pratami, \& Purwati, 2016) which states that emotional freedom and the search for adolescent identity are generally characterized by a higher number of social interactions with friends and the environment compared with parents. The intensity of social interactions that tend to come out is what is possible to trap teens in negative relationships. Based on the thought of social researchers have a very important role for every teenager, because at this time adolescents are very sensitive to the influence of new values, especially for those who do not have a strong stronghold then it will be very risky to experience relationships that tend to be negative such as premarital sexual relations.

Based on the results of the study conducted there were 55 respondents in which 40 people $(72.7 \%)$ had premarital sex, while 15 people $(27.3 \%)$ did not have premarital sex. Premarital sexual behavior is the biggest problem of adolescents in any region of the world, some things that are of particular concern about free sex are the spread of venereal disease, pregnancy outside marriage, abortion, termination of school and young marriage among adolescents. data and information center Ministry of Health Republic of Indonesia, 2014).

The above is in line with the results of a study (Suparmi \& Isfandari, 2016) conducted by the Republic of Indonesia Youth Health Unit (SKRRI) which states that 
adolescents who engage in premarital sexual relations have a greater risk for unprotected sexual behavior. This can increase the risk of contracting or transmitting disease and HIV / AIDS. In addition, adolescents will be more vulnerable to unwanted pregnancies and lead to abortions that can threaten the health and safety of adolescents. Researchers argue that the occurrence of premarital sexual behavior in adolescents because they do not fully understand the serious impact of sexual behavior before marriage and adolescents engage in sexual intercourse just for trial or pressure from social partners.

Based on the results of research conducted on high school adolescents, the total number of respondents was 55 people and it is known that of the 23 respondents who experienced low-risk relationships and did not have premarital sexual relations as many as 12 respondents (52.2\%), and low-risk associations of respondents and having premarital sex with 11 respondents (47.8\%). While of the 32 respondents who experienced high risk association and did not have sexual intercourse, 3 respondents (9.4\%) and adolescent association who were at risk and had premarital sex as many as 29 people (90.6\%). Sexual behavior is more risky for adolescents who spend more time together with peers. When adolescents spend time together, deviant behavior from one teenager can also be transmitted to his friend. Internalization and externalization of risky sexual behavior occur among adolescent friends (Suparmi \& Isfandari, 2016).

In line with the results of the study (Karyati, 2017) which states that one of the highest factors for adolescents engaging in premarital sex is association with the values of freedom in interacting with the opposite sex, making them at risk of being carried away. They will feel worried and afraid if considered old-fashioned or out of date if they do not follow the habits of the group. And not a few teenagers engage in premarital sex trial and error because of the support of friends (Karyati, 2017).

From the above results the researchers argue that the sexual behavior that occurs is not entirely desired by adolescents but there are external factors, one of which is the association that has been entered by a teenager. Pressure from peers who have had sexual relations can pressure adolescents who have not had sexual relations for reasons of friendship solidarity. 


\section{CONCLUSIONS}

High school teenage associations In Bulukumba Regency in 2018 most follow high risk associations. Premarital sexual behavior in high school adolescents In Bulukumba Regency in 2018 most respondents had had sex before marriage. a. It is expected to provide counseling about the dangers of promiscuity with the opposite sex early and to know about the association and the impact that will result.

\section{REFERENCES}

Abdissa, B., Addisie, M., \& Seiful, W. (2015). Premarital Sexual practies consequences and Associated Factors among Regular Undergraduate Female Students in Ambo University,Oromia Regional Stat, Central Ethiopia. Health Science Journal .

Badan Pusat Statistik Jakarta-Indonesia. (2008-2012). Analisis Data Perkawinan Usia Anak di Indonesia .

Darmayanti.y, Lestari, Y., \& Ramadani, M. (2011). Peran teman sebaya terhadap perilaku seksual pra nikah Siswa SLTA kota Bukittinggi. Jurnal kesehatan Masyarakat.

Inayatih, V., \& Pujiastuti, T. W. (2017). Faktor-faktor yang mempengaruhi pergaulan remaja.

Info Datin Pusat Data Dan informasi Kementrian Kesehatana Repoblik Indonesia. (2014, 06 sunday). Situasi Kesehatan reproduksi wanita .

karyati, S. (2017). Lingkungan Sosial, Teman sebaya, Spiritualitas Dan perilaku seksual pranikah remaja anak jalanan. Urecol Proceeding .

Rais, S. $(2015,12)$. Mirisnya pergaulan remaja saat ini .

(2018). Rakyatku.com. Bulukumba: Rahmatullah.

Soetjiningsih. (2010). Tumbuh Kembang Remaja dan Permasalahannya . Jakarta: Cv.Sagung Seto.

(2012,06). Retrieved from Psichologymania:

http://www.psychologymania.com/2012/06/pengertian-perilaku-sekspranikah.html

(2016, 03). Retrieved from Perkumpulan Keluarga Berencana Indonesia Daerah Istimewa Yogyakarta: http://pkbi-diy.info/pengertian-seks-dan-seksualitas/

Abdissa, B., Addisie, M., \& Seiful, W. (2015). Premarital Sexual practies consequences and Associated Factors among Regular Undergraduate Female Students in Ambo University,Oromia Regional Stat, Central Ethiopia. Health Science Journal .

Aningtias, A. r. (2015). Hubungan antara lingkungan pergaulan dengan sikap dan perilaku seks bebas remaja di SMK Murni 2 Surakarta.

Anirah, A., \& Hasnah, S. (2013). Pendidikan islam dan etika pergaulan usia remaja(Studi pada peserta didik MAN 2 model Palu. Jurnal Penelitian IImiah .

Annisa, B. v. $(2013,10)$. Retrieved from Hukum pedia.com: http://www.hukumpedia.com/bellavireyasa/love-is-not-about-sex 
Azinar, M. (2013). Perilaku seksual peranikah beresiko terhadap kehamilan yang tidak di inginkan. KESMAS.

Darmayanti.y, Lestari, Y., \& Ramadani, M. (2011). Peran teman sebaya terhadap perilaku seksual pra nikah Siswa SLTA kota Bukittinggi. Jurnal kesehatan Masyarakat.

Dwi Pratami, A. F., \& Purwati, Y. (2017). Hubungan Konformitas teman sebaya dengan perilaku seksual pranikah pada remaja SMP N 2 Tempel.

Fitrah, A. D. (2016,12). Retrieved 03 Selasa, 2018, from Firde 7: http://www.firde7.xyz/2016/12/pjok-pergaulan-sehat.html

Hasibuan, R., Dewi, Y. I., \& Huda, N. (2014). Faktor-Faktor Yang Mempengaruhi Kejadian Seks Pranikah Pada Remaja Putri Di SMAN 1 Pagai Utara Selatan Kabupaten Kepulauan Mentawai.

Herry. (2013, 01). teman sebaya. Retrieved 03 Jumat, 2018, from Wordpress.com: https://herrystw.wordpress.com/2013/01/05/teman-sebaya/

Inayatih, V., \& Pujiastuti, T. W. (2017). Faktor-faktor yang mempengaruhi pergaulan remaja .

Info Datin Pusat Data Dan informasi Kementrian Kesehatana Repoblik Indonesia. (2014, 06 sunday). Situasi Kesehatan reproduksi wanita .

Kajian Pustaka. (2017, 12 Kamis). Pengertian, bentuk dan faktor penyebab perilaku seks bebas.

Karyati, S. (2017). Lingkungan sosial, Teman Sebaya, Spiritualitas Dan Perilaku Seksual Pranikah Remaja Anak Jalanan. Urecol Proceeding .

Manyundarma. (2013). Retrieved 03 Selasa, 2018, from WordPress.com.

Naja, Z. S., Agushybana, F., \& Mawarni, A. (2017). Hubungan pengetahuan, sikap mengenai seksualitas dan paparan media sosial dengan perilaku seksual pranikah pada remaja di beberapa SMA Kota Semarang triwulan II . Jurnal kesehatan masyarakat.

Nugroho, A. (2017, 09 Jumat). Bahaya Seks Oral. Harian Nasional.

Rahyani, K. Y., Utarini, A., Wilopo, S. A., \& Hakimi, M. (2012). Perilaku seks pranikah remaja. Jurnal kesehatan masyarakat nasional.

Riadi, M. (2013, 04 Minggu). Pola asuh orang tua. Kajian Pustaka .

Sinaga, S. e. (2013). Faktor-faktor yang mempengaruhi perilaku seks pranikah pada mahasiswa akademi kesehatan X di Kabupaten Lebak.

Soetjiningsih. (2010). Tumbuh Kembang Remaja dan Permasalahannya . Jakarta: Cv.Sagung Seto.

Suparmi, \& Isfandari, S. (2016). Peran teman sebaya terhadap perilaku seksual pranikah pada remaja laki-laki dan perempuan di Indonesia . Buletin penelitian Kesehatan .

Su'ud, S. (2011). Remaja dan perilaku menyimpang. Selami IPS.

Wahyudi, N. $(2015,11)$. Retrieved 03 selasa, 2018, from Pengaruh positif dan negatif dalam pergaulan: http://nurwahyudi.mhs.narotama.ac.id/pengaruh-positif-dannegative-dalam-pergaulan/

Widiastuti, R. S. (2015). Hubungan pengetahuan bahaya pergaulan bebas pada remaja dengan persepsi perilaku seks pranikah di SMA N 1 Sewon Bantul. 


\section{COMPRABENSIVE HEAM GARE}

Wikimedia Bahasa Indonesia. (2018). Wikipedia enseklopedia bebas .

Willis, S. (2017). Remaja dan masalahnya (mengupas berbagai bentuk kenakalan ramaja narkoba, free sex dan pemecahannya . Bandung: Alfabeta.

Yosep, I., \& sutini, T. (2010). Buku Ajar Keperawatan Jiwa. Bandung: PT Refika Aditama.

Dahlan, M. (2010). Besar sampel dan cara pengambilan sampel. Jakarta: Salemba Medika.

Notoatmojo, S. (2012). Metode penelitian kesehatan. Jakarta: Rineka cipta.

Sugiyono. (2014). Statistika untuk penelitian. Bandung: Alfabeta.

Syamsuddin, Muriyati, Asnidar, \& Sumarni. (2015). Pedoman praktis metodelogi penelitian internal. Ponorogo: Wade grup.

Dahlan, S. (2016). Besar sampel dalam penelitian kedokteran dan kesehatan seri 2. Epidemiologi Indonesia.

Elvindri, Hasnita, E., Abidin, Z., \& Elmiyasna, R. M. (2012). Metodologi penelitian kesehatan. Jakarta: Baduose Media.

Setiadi. (2013). Konsep dan praktik penulisan riset keperawatan edisi 2. Yogyakarta: Graha Ilmu.

suyanto. (2011). Metodologi dan aplikasi penelitian keperawatan. Yogyakarta: Nuha Medika. 